\title{
Evaluating the effectiveness of university agricultural extension test stations using Wuli-Shili-Renli methodology
}

\author{
Tingting Liu ${ }^{1}$ Peijun Tao $^{1^{*}}$ (D) \\ ${ }^{1}$ College of Agronomy, Hebei Agricultural University, 071000, Baoding, Hebei, China. E-mail: taopeijun@sina.com. *Corresponding author.
}

ABSTRACT: Wuli-Shili-Renli (WSR) methodology was used to assess the effects of systematic management on university agricultural extension test stations, in order to understand areas for further optimization. We developed a framework model and evaluation index system, of which, the weights of the evaluation index system were determined using AHP. Using an agricultural extension test station of Hebei Agricultural University as an example, we interviewed and surveyed in total of 225 university extension experts from nine test stations. Assessment showed that the test station system organization produces desirable societal benefits and improvements. In addition, the organizational structure and job allocation were found to act as high-impact factors in improving the optimal system function, with the university extension experts functional better in the incentive and guarantee mechanism than other factors. Our investigation validated that the university extension experts were critical in designing the incentives and evaluation programs.

Key words: the WSR methodology, university agricultural extension, test station, framework model, evaluation index system.

Avaliação da eficácia de estações de teste de extensão agrícola universitária usando a metodologia Wuli-Shili-Renli

RESUMO: A metodologia Wuli-Shili-Renli (WSR) foi usada para avaliar os efeitos do manejo sistemático nas estações de teste de extensão agrícola da universidade, a fim de entender as áreas para maior otimização. Desenvolvemos um modelo de estrutura e um sistema de índices de avaliação, dos quais os pesos do sistema de índices de avaliação foram determinados com o AHP. Usando uma estação de teste de extensão agricola da Universidade Agrícola de Hebei como exemplo, entrevistamos um total de 225 especialistas em extensão universitária de nove estações de teste. A avaliação mostrou que a organização do sistema da estação de teste produz beneficios e melhorias sociais desejáveis. Além disso, verificou-se que a estrutura organizacional e a alocação de cargos atuam como fatores de alto impacto na melhoria da função ótima do sistema, com os especialistas em extensão universitária funcionando melhor no mecanismo de incentivo e garantia do que outros fatores. Nossa investigação validou que os especialistas em extensão universitária eram críticos no desenho dos incentivos e programas de avaliação. Palavras-chave: a metodologia WSR, extensão agrícola universitária, estação de teste, modelo de estrutura, sistema de índice de avaliação.

\section{INTRODUCTION}

One of the important functions of a university is to provide services to the public (CHEN $\&$ HE, 2015). The land-grant model used in some American universities has been recognized as a successful system for bringing the academic research achievements to the public. Agricultural extension in universities is a public-based research and disseminate knowledge to farmers (CHATTERJEE et al., 2018). The test stations at these universities act as part of the agricultural extension programs and serve as important platforms in transforming innovative agricultural technologies into widespread applications. These test stations have been operated and developed by many universities over past several decades, with significant benefits transferred to the local communities. Based on the test stations of landgrant universities, some Chinese universities have developed similar program models. One model, the "Quzhou model" was generated based on the premise of the known science and technology backyard (LI \& GAO, 2012). The China Agricultural University has explored this model based on research and service in Quzhou County of Hebei Province over 46 years, which integrates the agricultural science and education achievements. Through innovative soil technologies introduced by the university's research, 
15333.33 ha of saline-alkali land has been converted into the arable field suitably for growing rice-grain. In 1973, the agricultural food production in this area was less than $1500 \mathrm{~kg}$ per ha and it currently has been improved to an average annual yield of more than $15000 \mathrm{~kg}$. Another model developed in China is the "Xinong model," which involves strategic integration of three stations: a test station, a regional demonstration station, and a science and technology promotion station (CHEN, 2013). Using this model, Northwest A\&F University has established and coordinated 27 industrial trial demonstration stations, 46 demonstration bases and more than 100 science and technology demonstration parks across 15 provinces in the country. The university's extension program has been widely recognized for providing the surrounding community requirements. A third model is Huzhou's " $1+1+\mathrm{N}$ model," which concentrates on follow aspects: i. an expert team of colleges and universities, and ii, local experts of cities and counties that serve $(\mathrm{N})$ agricultural operation subjects. At Zhejiang University, in total of 104 extension experts have worked with 221 soil experts in local cities and counties to serve more than 1,400 farmers and agricultural business workers.

University agricultural extension plays a critical role in supporting new agricultural businesses in China. In 2012, the Central Committee proposed for the first time that "colleges and universities and scientific research institutes should guide and become an important force for public welfare agricultural technology promotion, the service performance of agricultural technology promotion should perform professional and technical post evaluation and work assessment, and the promotion professor and promotion researcher system should be effectively implemented (CPC CENTRAL COMMITTEE, 2012)". As on June 2019, 39 colleges and universities in China offered agricultural extension services. As part of these services, more than 300 test stations have been established, which cover more than 500 academician and expert workstations, nearly 1,400 agricultural extension demonstration bases, and characteristic industrial bases. More than 1,700 related agricultural enterprises have been initiated. These efforts lead to increased output nearly 600 billion yuan (MINISTRY OF EDUCATION, 2019).

Though the demonstrated value of China's university agricultural extension programs, the issues including how to distribute and structure test stations, motivate extension specialists, and design test stations that support integrating the novel technologies into public agricultural contexts are still to be further addressed. At present, the agricultural extension test stations underlying university management are mainly divided into vertical topdown management, chief expert responsibility system management, cooperative flat management. The vertical management and chief expert responsibility systems are effective on the organization and execution, but in shortage of enthusiasm of experts. The flat management is advantage of the improved management efficiency realized by reducing management level, but its large scope limits the coordination ability. Thus, further improving efficiency and effect of the agricultural extension by agricultural extension test station in universities has been paid more attention. In management view of both advantage and disadvantage of the university test station system, we evaluated the effectiveness of agricultural extension test stations at universities (referred to as "test stations") by using the WSR methodology framework, to provide evidence-based theoretical guidance for continued state funding of Chinese universities that promote public welfare through agricultural extension programs. In this study, our purposes are as follows: (i) to investigate the present research on test station and the WSR methodology at home and abroad; (ii) to analyze the WSR framework model in test stations and designing the research plan and questionnaire; (iii) to verify the model using an test station of Hebei Agricultural University as an example.

\section{LITERATURE REVIEW}

The importance of test stations to agricultural extension of universities

Scholars from China and around the world have studied the agriculture extension models using university experimental station as a research objective (SATTAKA et al., 2017; FIAZ et al., 2018; VERMA \& SINHA, 2018; PAN \& SINGHAL, 2019; ALZAHRANI et al., 2019). The consensus of many literature reviews, case studies and empirical investigations is that the universities play key roles in agricultural extension and the test stations are the most valuable in supporting agricultural development. However, there remains much research and debate on how to specifically design and distribute test stations and how to transfer the enthusiasm of the test station staffs into tangible benefits to public. At American agricultural colleges, the experimental station is the main research institution as well as the promotion demonstration point. It is not only the organizer of the state promotion work, but also the implementer 
of the promotion plan, given its connection between the agricultural technology and the farmers (TRUE, 1899; LISTED, 1979). Through studies performed at the University of Wisconsin-Madison, CHAPMAN et al. (1992) found that universities engaged in agricultural extension have the built-in advantage of promoting agricultural occupational health research, which promotes the school development while also benefits technology and information services. Based on a detailed case study, HE (2012) reported that the "Agricultural and Forestry University Model" acts as an important supplement to currently national agricultural extension system, of which, the agricultural test station is critical in the university agricultural extension. In a literature review, TIAN \& CHEN (2013) reported on some issues related to how colleges and universities structure their agricultural extension programs, including layout, lack of guarantee of conditions, and in shortage of incentive policies. The authors proposed suggestions for strengthening the top-level design, clarifying the base construction standards and improving the incentive evaluation mechanism. The test station helps implement technology and increases crop yields in farmers' fields by providing consultation, demonstration and training the farmers. Additionally, it has eliminated the gaps between experts and farmers, scientific research and production, and education and implementation (TANG et al., 2015; RACHEL \& ABIODUN, 2018; STUART, 2018). WEN et al. (2018) analyzed the interactive relationship among government, industry, universities, research and extension and proposed a way to coordinate these aspects: taking government guidance and scientific-technological innovation as the driving forces, enterprises as the main body, universities and scientific research institutes as the technical support, and the projects as the link. ZHANG et al. (2018) established the internal and operational mechanisms of the apple industry using Xinong's "three stationchain integration" model. The authors elucidated follow strategy by improving the role of universities in serving society: intimate connection among layout and management of the core test station, regional demonstration station, and science and technology promotion station, and demand of the whole agricultural industry chain.

\section{Managementsystem application of WSR methodology}

University agricultural extension test stations involve a complex social system affected by many interrelated factors. Therefore, designing and improving the test station management requires a kind of systems approach. Wuli-Shili-Renli (referred to as "WSR") acts as a methodology frequently used in China to quantitatively and qualitatively address the complex integrated systems. This approach considers and balances the principles of physics (Wuli), reason (Shili) and human relations (Renli) within the system scope to achieve optimal outcomes. Many studies have demonstrated the effectiveness of the WSR methodology in practical applications. SHE (2006) established a successful project managementWSR system model for the Guangzhou University City project, focusing on human participation, coordination and comprehensive integration. GU et al. (2007) conducted a comprehensive case review in which the WSR methodology has been applied in China and elsewhere, and found that the cases involved wide variety systems of organizations, projects and university management. XIAO \& ZENG (2012) have presented incentive mechanism framework researchers to use institutional knowledge based on the WSR theory. The framework utilizes incentive mechanisms within dimensions of knowledge, environment and employees. According to XUE et al. (2012), the WSR system methodology can guide systems analysts to methodically and logically approach the whole project process that ensures specific elements without negative impact on the entire system. Tao (2015) established a three-dimensional analysis model on managing organizational crisis based on WSR methodology; the three dimensions included physics (organization and environment system state and evolution), reason (crisis evolution mechanism) and human principles (early warning procedure). WANG et al. (2017) reconstructed the framework model of agricultural extension under WSR methodology guidance that reflects modern physical, administrative and human conditions of agricultural extension. JI et al. (2018) developed a public building and energy management platform and evaluation index system based on the WSR methodology, which identified the ways to improve the management platform. In the current study, we use the WSR methodology that covers physics, reason and human relation principles to develop a model and index system for the agricultural extension test stations of universities.

\section{MODELS AND METHODOLOGY PROCEDURES}

The WSR framework model and evaluation index system Figure 1 shows the WSR framework model as applied to the agricultural extension 


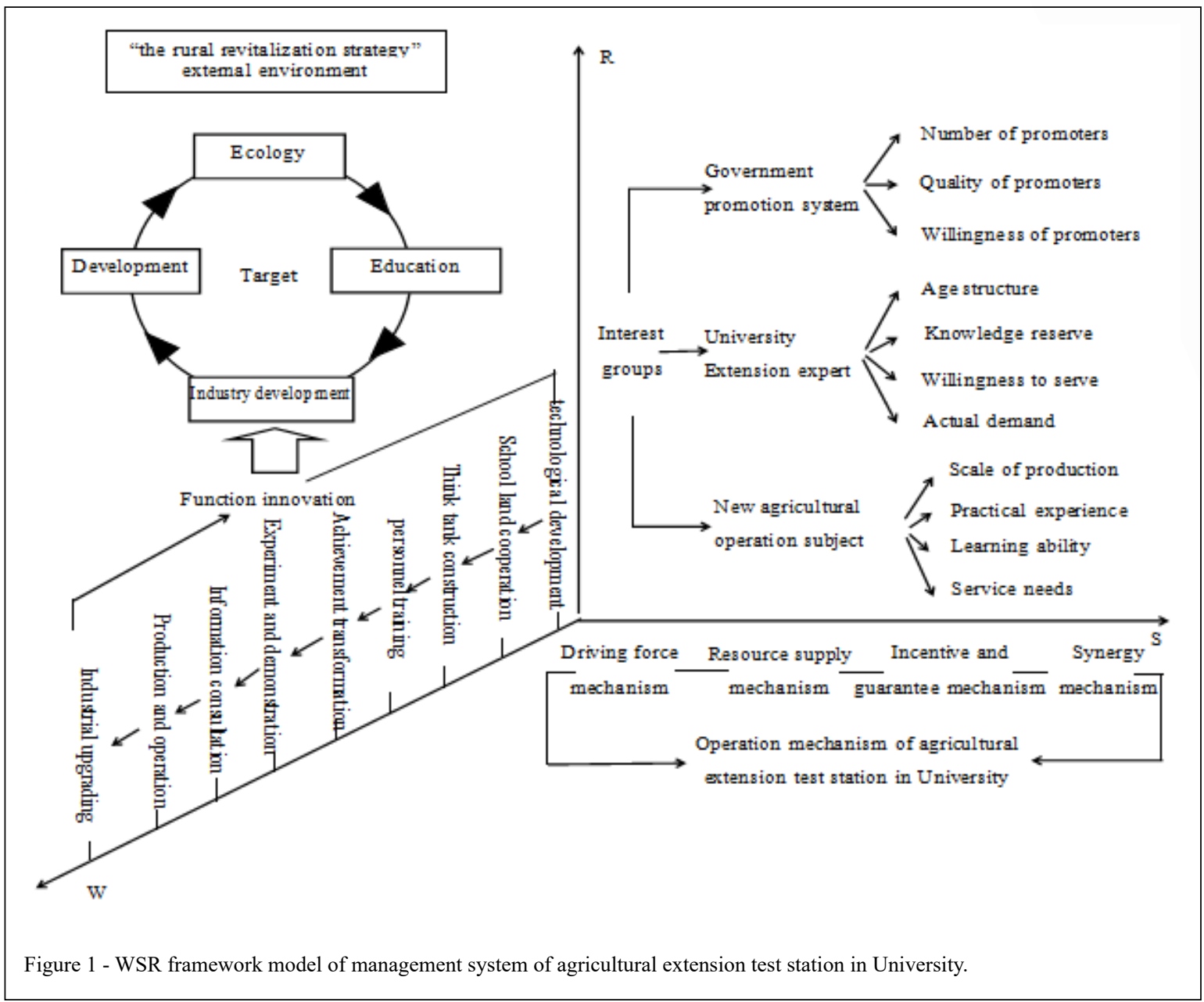

test stations of universities. The physics (Wuli) component, which is related to the objective existence in system, contains nine functions and four goals for the test stations. These function modules provide the whole industry service chain for a new agricultural operation subject and promote the accomplishment of four goals of ecology (protecting environmental ecology), education (educating farmers and students), industry development (revitalizing local agricultural industries), and development (agricultural improvements that support sustainability). The reason component (Shili) or why to do things is represented by operating the test stations. Following four mechanisms work together to achieve sustainable development of the test stations: driving-force mechanism, resource-supply mechanism, incentives and guarantee mechanism and cooperation mechanism. The human relations principle (Renlii) is expressed as the impact of human behavior, purpose, psychology and environment on human beings. In the model, the human relations factors include: selecting a team of extension experts that connects the relation between the government extension workers and new agricultural businesses. The most critical human relations factor identified in the model is the extension experts and how to assess them as well as how to provide effective incentives (details provided in later sections).

Correct systematic management strategy can improve the service value of the test stations. Based on relevant reports, the current status of test stations evaluated by the WSR framework model and the opinions of university extension experts have been described in previous studies by integrating the physics (Wuli), reason (Shili) and human relations (Renli) principles, which acted as the first-level indicators (GUO \& LUO, 2013). At the physics level, the functions and objectives of the test stations are 
considered based on indicators of organizational structure, function, layout and technological innovation. At the reason level, the mechanisms of test station operation are highlighted by driving force, resource supply, incentives and guarantees, and coordination as the secondary indicators. At the human relations level, the test station extension experts are evaluated in terms of number of experts, technical reserves of experts, willingness of experts to serve, and actual needs of experts. The designed evaluation index system includes three first-level indicators and 12 second-level indicators (LIN et al., 2013), as shown in table 1.

The analytic hierarchy process (AHP) has been a decision-making method for assigning the hierarchical weight designed by American operational research scientist Sa Ti. In AHP, the weights are assigned to each of the indicators within the WSR-test station model. Firstly, extension experts in universities are invited to build hierarchical models and comparison matrices. For comparing the importance of an element $i$ and an element $j$ relative to a factor in the upper layer, the quantitative relative weight $a_{i j}$ is used. Secondly, calculation of the weight vector and performance of the consistency test.
Thirdly, calculation of the combination weight vector and running of the combination consistency test. In this study, assignment of the first-level indexes, second-level indexes and system weights were conducted according to the AHP weight vector.

As shown in table 2, the weights assigned to $\mathrm{W}, \mathrm{S}$ and $\mathrm{R}$ in the first-level index for the test station system model were $0.3275,0.2599$ and 0.4126 , respectively. It is notable that $\mathrm{R}$ rated as more highly significant than $\mathrm{W}$ or $\mathrm{S}$, indicating that the university extension experts play the greatest impact in evaluating the test station management. Among the secondary indicators, the order of importance based on the model was shown as follows: demands of experts (most impact), followed by experts' willingness to serve, technology reserve of experts, and number of experts (last two carried equal weight). It is notable that the system weights given for actual expert needs (which is more specifically described in table 1 as "the treatment, professional title promotion and evaluation system of university extension experts are reasonable") is 0.2500 , accounting for a quarter of weights assigned to the whole group that covers 12 secondary indicators. Two other secondary indicators carried a weight of more than 0.1 , including the

Table 1 - Evaluation index system of management system of agricultural extension test station based on WSR methodology.

\begin{tabular}{|c|c|c|}
\hline Essential factor & index & Index metric \\
\hline \multirow{4}{*}{ physical（wuli） } & Organizational structure of test station w1 & $\begin{array}{l}\text { The organizational structure of the test station is clear and the post } \\
\text { setting is reasonable }\end{array}$ \\
\hline & Function of test station w2 & $\begin{array}{l}\text { The test station has complete functions and has the hardware and } \\
\text { software conditions to realize the functions }\end{array}$ \\
\hline & Layout of test station w3 & The number and layout of test stations is rational \\
\hline & Technological innovation of test station w4 & $\begin{array}{l}\text { As the source of technological innovation, the test station regularly } \\
\text { produces new technologies and achievements }\end{array}$ \\
\hline \multirow{4}{*}{ reason (Shil) } & Driving force mechanism of test station s1 & $\begin{array}{c}\text { Government departments and universities attach great importance } \\
\text { to agricultural extension work and provide corresponding material } \\
\text { support }\end{array}$ \\
\hline & $\begin{array}{l}\text { Resource supply mechanism of test station } \\
\text { s2 }\end{array}$ & $\begin{array}{c}\text { The investment of people, money and materials can satisfy the } \\
\text { operation of the test station }\end{array}$ \\
\hline & $\begin{array}{l}\text { Incentive and guarantee mechanism of test } \\
\text { station } \mathrm{s} 3\end{array}$ & $\begin{array}{l}\text { Provide comprehensive policy incentives and institutional } \\
\text { safeguards for university agricultural extension experts }\end{array}$ \\
\hline & Cooperative mechanism of test station s 4 & $\begin{array}{l}\text { There is cooperation between government extension system and } \\
\text { new agricultural management subjects }\end{array}$ \\
\hline \multirow{4}{*}{$\begin{array}{l}\text { human principle }( \\
\text { renli) }\end{array}$} & Number of University promotion experts $\mathrm{r} 1$ & $\begin{array}{l}\text { The number of university extension experts is sufficient to meet the } \\
\text { needs of existing services }\end{array}$ \\
\hline & $\begin{array}{l}\text { University Extension expert technology } \\
\text { reserve } \mathrm{r} 2\end{array}$ & $\begin{array}{l}\text { The knowledge and technology of university extension experts can } \\
\text { solve problems in production }\end{array}$ \\
\hline & $\begin{array}{l}\text { Willingness of University Extension } \\
\text { experts to serve r3 }\end{array}$ & $\begin{array}{l}\text { University promotion experts have strong willingness to serve and } \\
\text { strong enthusiasm for work }\end{array}$ \\
\hline & $\begin{array}{l}\text { Actual needs of University Extension } \\
\text { experts } \mathrm{r} 4\end{array}$ & $\begin{array}{l}\text { The treatment, professional title promotion and evaluation system } \\
\text { of university extension experts are reasonable }\end{array}$ \\
\hline
\end{tabular}

Ciência Rural, v.51, n.1, 2021. 
Table 2 - Weight of management system evaluation indexes for university agricultural extension test stations.

\begin{tabular}{|c|c|c|c|c|}
\hline \multicolumn{2}{|c|}{----------Primary index (weight)--------- } & \multicolumn{2}{|c|}{ 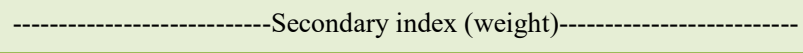 } & \multirow{2}{*}{$\begin{array}{c}\text { System weight } \\
0.1814\end{array}$} \\
\hline \multirow{4}{*}{ physics (wuli) } & \multirow{4}{*}{0.3275} & Organizational structure of test station w1 & 0.5538 & \\
\hline & & Function of test station w2 & 0.1258 & 0.0412 \\
\hline & & Layout of test station w3 & 0.2477 & 0.0811 \\
\hline & & Technological innovation of test station w4 & 0.0727 & 0.0238 \\
\hline \multirow{4}{*}{ reason (Shili) } & \multirow{4}{*}{0.2599} & Driving force mechanism of test station $\mathrm{s} 1$ & 0.0905 & 0.0235 \\
\hline & & Resource supply mechanism of test station s2 & 0.2344 & 0.0609 \\
\hline & & Incentive and guarantee mechanism of test station s3 & 0.5955 & 0.1548 \\
\hline & & Cooperative mechanism of test station s4 & 0.0796 & 0.0207 \\
\hline \multirow{4}{*}{ human principle (renli) } & \multirow{4}{*}{0.4126} & Number of University promotion experts $\mathrm{r} 1$ & 0.0921 & 0.0380 \\
\hline & & University Extension expert technology reserve r2 & 0.0921 & 0.0380 \\
\hline & & Willingness of University Extension experts to serve $r 3$ & 0.2099 & 0.0866 \\
\hline & & Actual needs of University Extension experts r4 & 0.6059 & 0.2500 \\
\hline
\end{tabular}

organizational structure, and the incentive and guarantee mechanism of the test station. Three indicators were assigned weights within 0.05 to 0.1 : the experts' willingness to serve, layout of the test station and resources-supply mechanism of the test station. Together, these six indicators accounted for $81.48 \%$ of total weight, indicating the significance of these factors for the effectively functional test stations.

\section{Definition and implementation of the questionnaire}

Test items in the WSR-test station questionnaire were scored with the Likert 5-level scale method, with scores 1, 2, 3, 4 and 5 to stand for "very dissatisfied," "dissatisfied," "generally satisfied," "satisfied" and "very satisfied," respectively. A total of 225 experts from nine Hebei Agricultural University test stations were selected to be subjected to interviews and completion of the questionnaire (test stations classified according to the location, with expert number marked by Shunping-28, Zhangbei-17, Mancheng-22, Lincheng-36, Longhua-16, Xinji-31, Zhongjie-21, Qingyuan-26, and Qingxian-28, respectively). The experts during interviews were asked time availability and willingness to participate in university agricultural extension, to play roles and practices using the test station, to solve problems and difficulties encountered, to understand factors influencing the effectiveness, and to manage and operate the test station. As described in previous section, the questionnaire included 12 measurement items in three dimensions covering physics, reason and human relations. Statistical results related to the questionnaire are shown in table 3.

Scores of the 12 survey items were ranged from 1 to 5, with averages between 3.4 and
4.3 and standard deviations between 0.6 and 0.8 . Four survey items scored an average less than 4 points, including the organizational structure of test station, incentive and guarantee mechanism of test station, experts' willingness to serve, and the actual expert requirements, which indicated that the experts' satisfaction degree with four indicators needed to be improved for optimal management system. According to weights and mean values of the evaluation index system, the overall satisfaction score was 3.822 , situated at the scale between "general satisfaction" and "satisfaction".

\section{CASE ANALYSIS}

Layout of university agricultural extension and test stations

Hebei Province covers six distinct ecological regions that share characteristics with broad ecological regions across the globe. Thus, it is significant in the layout of university agricultural extension and test stations in these distinct zones. In past two decades, Hebei Agricultural University has set up nine agricultural extension and test stations in Hebei Province (Figure 2). Sites of them were selected based on the agricultural industries to be suitable to the regional characteristics. The test stations were then established in the agricultural centers and run by multi-disciplinary expert teams assembled according to needs of the particular agricultural industry and new local agricultural operators. The strategy was shifted from the traditional extension "supply side" to "demand side" by identifying production problems and addressing them in a timely manner. 
Table 3 - Statistical analysis of WSR-test station questionnaire results.

\begin{tabular}{|c|c|c|c|c|c|}
\hline & Survey item & $\begin{array}{l}\text { Minimum } \\
\text { value }\end{array}$ & $\begin{array}{l}\text { maximum } \\
\text { value }\end{array}$ & $\begin{array}{l}\text { mean } \\
\text { value }\end{array}$ & $\begin{array}{l}\text { standard } \\
\text { deviation }\end{array}$ \\
\hline \multirow{4}{*}{ physics (wuli) } & $\begin{array}{l}\text { The organizational structure of the test station is clear } \\
\text { and the post setting is reasonable }\end{array}$ & 2 & 5 & 3.819 & 0.799 \\
\hline & $\begin{array}{l}\text { The test station has complete functions and has the } \\
\text { hardware and software conditions to realize the } \\
\text { functions }\end{array}$ & 2 & 5 & 4.199 & 0.692 \\
\hline & The number and layout of test stations is rational & 2 & 5 & 4.138 & 0.781 \\
\hline & $\begin{array}{l}\text { As the source of technological innovation, the test } \\
\text { station regularly produces new technologies and } \\
\text { achievements }\end{array}$ & 2 & 5 & 4.285 & 0.759 \\
\hline \multirow{4}{*}{ reason (shili) } & $\begin{array}{l}\text { Government departments and universities attach } \\
\text { great importance to agricultural extension work and } \\
\text { provide corresponding material support }\end{array}$ & 1 & 5 & 4.018 & 0.817 \\
\hline & $\begin{array}{l}\text { The investment of people, money and materials can } \\
\text { satisfy the operation of the test station }\end{array}$ & 1 & 5 & 4.181 & 0.809 \\
\hline & $\begin{array}{c}\text { Provide comprehensive policy incentives and } \\
\text { institutional safeguards for university agricultural } \\
\text { extension experts }\end{array}$ & 1 & 4 & 3.472 & 0.645 \\
\hline & $\begin{array}{l}\text { There is cooperation between government extension } \\
\text { system and new agricultural management subjects }\end{array}$ & 2 & 5 & 4.226 & 0.782 \\
\hline \multirow{4}{*}{$\begin{array}{l}\text { human principle ( } \\
\text { renli) }\end{array}$} & $\begin{array}{l}\text { The number of university extension experts is } \\
\text { sufficient to meet the needs of existing services }\end{array}$ & 2 & 5 & 4.059 & 0.815 \\
\hline & $\begin{array}{l}\text { The knowledge and technology of university } \\
\text { extension experts can solve problems in production }\end{array}$ & 3 & 5 & 4.289 & 0.652 \\
\hline & $\begin{array}{l}\text { University promotion experts have strong willingness } \\
\text { to serve and strong enthusiasm for work }\end{array}$ & 2 & 4 & 3.738 & 0.777 \\
\hline & $\begin{array}{l}\text { The treatment, professional title promotion and } \\
\text { evaluation system of university extension experts are } \\
\text { reasonable }\end{array}$ & 1 & 4 & 3.615 & 0.682 \\
\hline
\end{tabular}

In this study, the Shunping test station situated in lowmountain, hilly region was selected as the sample for analysis. The test station was jointly financed and constructed by Hebei Agricultural University and the Shunping County government. For three consecutive years, the county government has invested 300,000 yuan for construction of preliminary experimental stations and demonstration areas, followed by 3.5 million yuan provided by government poverty alleviation project funds. In addition, the university provided funds to purchase scientific research instruments and equipment and to pay expert scientific research. All of which fall under S dimension in the WSR framework model. The test station is equipped with a supporting scientific research center, teaching and training room, meteorological information monitoring system, remote control service system, cold storage, fruit selection base, organic fertilizer plant, experimental demonstration area. At present, in total of 103 apple varieties and 27 dwarfing rootstocks have been introduced from China and around the globe to conduct the experimental research. At this stage, the main research and extension goal on apple dwarfing and close planting technology has created an 5.33ha apple experimental field with high-standard drip irrigation for scientific and research experimentation, student practice and experimental demonstration. These components are categorized into scope of $\mathrm{W}$ in the WSR framework model. Jianshe Sun, a professor specialized at fruit cultivation at the Horticulture College of Hebei Agricultural University, is the chief expert of the test station. The resident experts of test station are all from various colleges at Hebei Agricultural University, with specialties in areas of fruit trees, pest control, agricultural machinery, meteorology, marketing and other disciplines, corresponding to $\mathrm{R}$ in the WSR framework model.

Service effect of agricultural extension test station in university

The expert team constituted by Hebei Agricultural University established the "three 


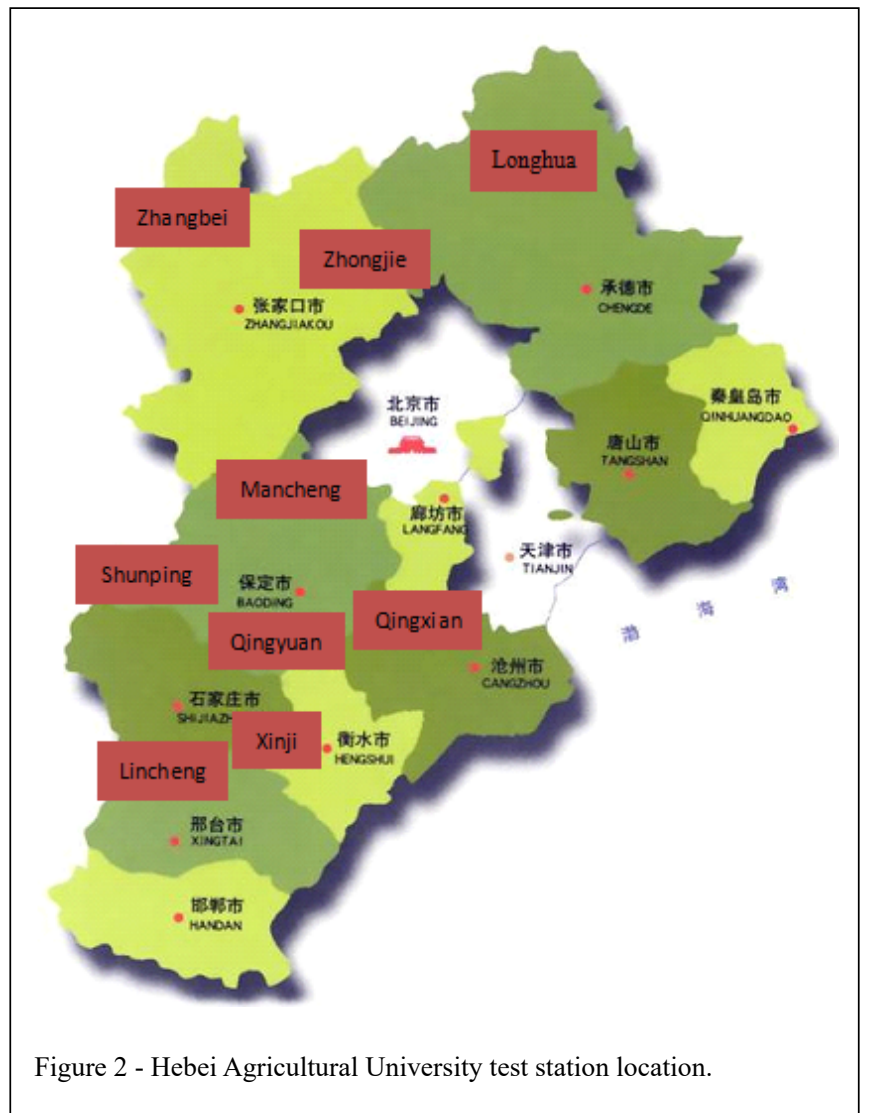

excellent" dwarf-stock dense-planting apple cultivation mode, which has been the main push technology of the test station. The selected dwarf rootstocks and dense planting have been widely used by various countries with advanced the apple production operations. It has advantages by small trees, easy operation, and efficient land use. Specifically, the "three excellent" method is typified by a fine-tuned version on apple cultivation mode. After more than 30 years of research, two new Fuji apple cultivars referred to as "Tianhong No. 1" and "Tianhong No. 2 " have been selected since of their resistance to cold, small size, early fruiting and high quality of fruit. The system combines "excellent variety," "excellent rootstock" and "excellent cultivation management technology", and has demonstrated earlier output and higher ratios of high-quality fruit compared with other dwarf-stock dense-planting operations. The technique is potential in significantly increasing the economic benefits of orchard production.

In order to encourage farmers to adopt this strategy, the test station experts planted apple trees in the experimental demonstration area using the preferred technique and invited agricultural business innovators and fruit farmers to visit the orchards. They recorded the input and output and conducted economic benefit analysis based on the data. These actions demonstrated successful implementation of the "three excellent" cultivation mode and were further shared with the farmers. Since the new cultivation method was introduced, the adoption rate by farmers and agricultural workers across county and surrounding areas has been increased yearly. Therefore, the test station has realized demonstration and promotion functions to promote technology innovations in fruit industry, new technology research and development, science and technology training, and talent training.

Benefits of university agricultural extension test stations (1) Economic benefits

In 2006, the expert team of Hebei Agricultural University took the lead in promoting the "three-excellent" cultivation method and supported technology for Fuji apple cultivation in Nanshennan village, Shunping County. The cultivation and

Ciência Rural, v.51, n.1, 2021. 
management increased the proportion of high-quality fruit to over $95 \%$, bringing considerably economic benefits to fruit farmers. Figure 3 shows that from 2014 to 2018, the apple planting area in Shunping county has increased from 3666.67 ha to 5333.33 ha, with output increase from 55 million $\mathrm{kg}$ to 67.5 million $\mathrm{kg}$ and output value increase from 160 million yuan to 500 million yuan. By the end of 2018, Shunping county had apple planting area of 5333.33 ha, which produced fruits of 135 million $\mathrm{kg}$ and output value of nearly 500 million yuan, leading to increase of average annual income of fruit farmers by more than 3,000 yuan and benefit of more than 12,000 people in eight poor villages (LI, 2019).

\section{(2) Social benefit}

Shunping test station has guided the apple industry onto a path of continuous change from traditional methods to "scientific production," from single-household production to multi-plantation agglomeration, and from simple sales of commodity fruit to deep processing (i.e., juicing and brewing). In collaboration with the county government, the chief expert of test station formulated the forest fruit development idea: "building a base on the mountain, establishing a market under the mountain, finding a market outside the mountain, and creating high efficiency through science and technology." With help of the expert team of test station, four "three excellent" Red Fuji apple demonstration parks more than 66.67 ha in area have been built (located at Nanshennan, Dongyang, Gezhuang, and Hejiaying, respectively) with resulted revenue more than 300000 yuan per ha. The Shunping experimental station created 42 additional demonstration sites and 3333.33 ha of demonstration areas (in Dongyang, Gezhuang,
Nantaiyu, Beidabei, etc.), which together covered an area of 5333.33 ha. Through these initiatives, Hebei has developed a positive relationship with the local fruit farmers by the demonstrated public benefits provided by test stations.

\section{(3) Ecological benefit}

In addition to increased output of crops and financial benefits for the farmers, the Shunping test station also has achieved significant ecological benefits. The dwarf-stock, wide row and dense planting cultivation technique promoted by experts of the test station has been becoming techniques for leading apple cultivation. This planting mode reduces the fertilizer amount as well as the application frequency, promoting the green development of the Shunping's apple industry. A simple technology integrated water and fertilizer has been widely used to maintain the ecosystem stability. In addition, the root system of trees stabilizes the soil and the trees reduce the wind-induced soil erosion, thus protecting the ecological environment.

\section{RESULTS AND DISCUSSION}

Nine functions and four objectives were characterized within physics (W) dimension underlying the WSR-test station framework (WANG \& LI, 2019). In the evaluation index system, four indexes were set up, including organizational structure, function, layout and technical innovation in a test station with the system weights of 0.1814 , $0.0412,0.0811$ and 0.0238 , respectively, and the average values of $3.819,4.199,4.138$ and 4.285 , respectively (BALOCH \& THAPA, 2019). Among the four indicators, the highest weight and the lowest

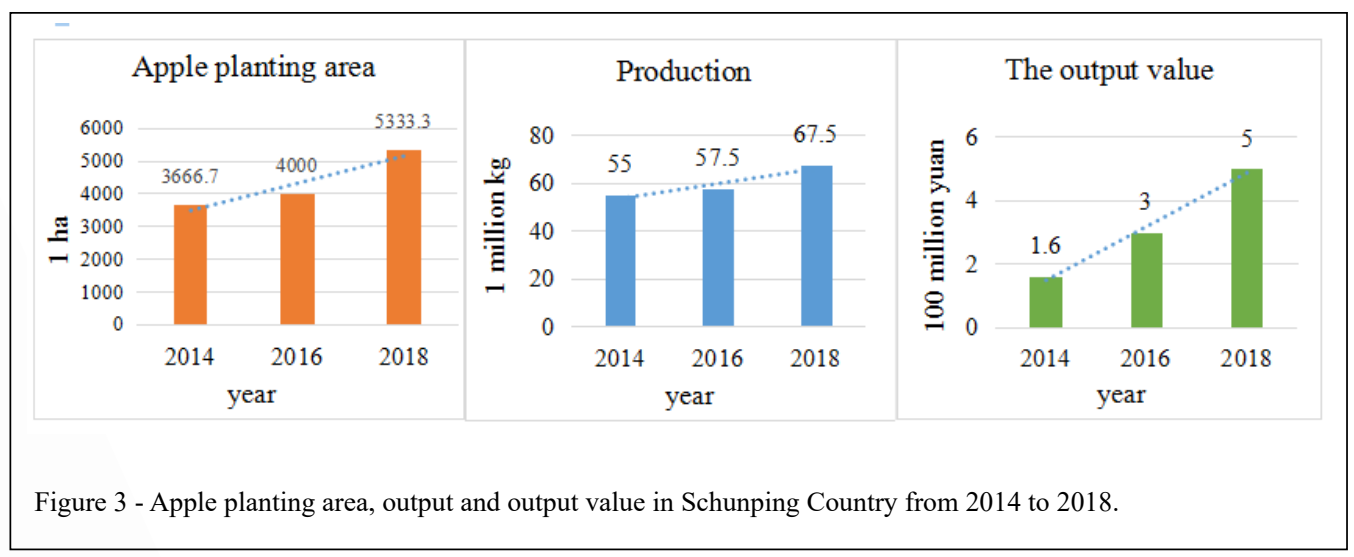

Ciência Rural, v.51, n.1, 2021. 
average score were dependent on the organizational structure indicator. The structure determines the function, and the reasonable post-setting improves the work efficiency and enthusiasm of the promotion experts. The test station layout score was 4.199, which is situated at scopes between satisfactory and very satisfactory. At present, the construction and layout of agricultural extension and test stations in universities are set up according to particular ecological areas all over the world, which effectively support the local industrial development and the technical agricultural operations (MINH, 2019). The average score of the technical innovation index was 4.285, which is higher than the other three indices, indicating that the technical innovation of test stations meets expectation of the university extension experts, as reported previously by ZHANG et al. (2016).

Four operation mechanisms were covered within reason (S) dimension of the WSR-test station framework, including driving-force mechanism, resource-supply mechanism, incentive and guarantee mechanism, and coordination mechanism. The system weights assigned to these mechanisms were 0.0235 , $0.0609,0.1548$ and 0.0207 , with mean values of 4.018 , $4.181,3.472$ and 4.226, respectively. Based on the weight and scores, the most important with lowest-scoring factor was the incentive and guarantee mechanism, valuing university extension experts this factor most (MOYO \& SALAWU, 2018). The current average satisfaction level is "general satisfaction." In subsequent optimization efforts for the test station system, there should be focused on designing the incentive and guarantee systems (BRUCE \& COSTA, 2019).

Government extension personnel, university extension experts, and new agricultural operation subjects are grouped within human relation (R) dimension of the WSR-test station framework. In the evaluation index system, test station experts were taken as the main group of interest with four indexes set up, including the number of extension experts, technical reserve of extension experts, extension expert willingness to serve, and the extension expert requirements. The system weights were 0.0380 , $0.0380,0.0866$ and 0.2500 , with average values of $4.059,4.289,3.738$ and 3.615, respectively. Therefore, it can be inferred when the university agricultural extension experts are evaluated and encouraged, full account of the nature and characteristics should be taken by the agricultural extension of the university, as reported by REID (2018). The quality and effect of the agricultural extension service should be taken as evaluation standard, of which, the active participation of university experts serves as the guidance, and incentive and evaluation programs suitably customized for agricultural extension personnel. Incentives should be evaluated according to expert needs at different experience levels (REZVANFAR et al., 2014). For example, for the experts esteemed with professional titles, many years of experience and good salaries, their incentives may include travel abroad, receive honors or allowances. For the young extension experts, the experts' preferential index should link the title evaluation policy, in which, the policy inclination links the promotion opportunity, and bonus that promoted them effectively.

The assessment showed that the test station system organization produces desirable societal benefits and improvements. The local government should introduce policies to encourage and support the test stations by carrying out agricultural extension services. Universities should introduce the independent promotion, welfare and evaluation systems, and modern evaluation methods, so as to fully mobilize the enthusiasm of extension experts. Additionally, the universities can promote the research and experience development of the test stations to other countries and regions in the following ways. Firstly, academic seminars should be held to encourage more agricultural experts understand the extension mode and achievements of the test stations. Secondly, universities should establish relations with foreign institutions by which to promote the model of test stations. Thirdly, the technical achievements and management experience of test stations should be publicized through agricultural website, WeChat official account, newspaper and other mass media. Different countries and regions around the world may run and improve the management system of the test stations according to their actual situation, with reference to promoting experience methods and the management systems of the test stations construction, by which to improve the model of the test stations and to solve local problems of agricultural extension.

Due to the differences in resource endowment and agricultural extension system scross different countries and regions, the research results in this study which selected the test stations of Hebei Agricultural University as a case, may have limitations in other regions or countries.

\section{CONCLUSION}

Technology innovation and achievement transformation are critical for agricultural extension in the developing countries. To sustainably develop the test station model, experts should pay more attention 
to the management area of Wuli, Shili and Renli, considering fullly the actual demands to promote experts and farmers, formulate corresponding incentive evaluation mechanism, motivate promotion work, and collect farmer needs by which to establish a bottom-up participatory promotion plan. According to conclusions that the university extension experts possess higher incentive and guarantee mechanism values, the university extension expert appeals were identified as the important basis for designing incentives and evaluation programs. Universities should promote the development of test stations to other countries and regions through academic research, science and technology commissioners, international cooperation, and mass media. These measurements benefit effectively transformation of agricultural development model and provide reference for the establishment of modern rural area in developing countries.

\section{ACKNOWLEDGEMENTS}

This work was supported by the National Key Research and Development Program of China (2018YFD0300507).

\section{DECLARATION OF CONFLICT OF INTERESTS}

The authors declare no conflict of interest. The founding sponsors had no role in the design of the study; in the collection, analyses, or interpretation of data; in the writing of the manuscript, and in the decision to publish the results.

\section{AUTHORS' CONTRIBUTIONS}

All authors contributed equally to the conception and writing of the manuscript. All authors critically revised the manuscript and approved of the final version.

\section{REFERENCES}

ALZAHRANI, K. H. et al. Perceptions of wheat farmers toward agricultural extension services for realizing sustainable biological yields. Saudi Journal of Biological Sciences, v.26, n.7, p.1-6, 2019. Available from: <https://www.researchgate.net/ publication/331007854_Perceptions_of_wheat_farmers_toward agricultural extension services for realizing sustainable biological_yields>. Accessed: Dec. $1 \overline{3}, 2019$. doi: 10.1016/j. sjbs.2019.02.002.

BRUCE, K.; COSTA, H. Enabling environment for PPPs in agricultural extension projects: Policy imperatives for impact. Journal of Rural Studies, v.70, p.87-95, 2019. Available from: $<$ www.sciencedirect. com/science/article/abs/pii/S0743016718309823>. Accessed: Apr. 8 , 2020. doi: 10.1016/j.jrurstud.2019.07.005.

BALOCH, M. A.; THAPA, G. B. Review of the agricultural extension modes and services with the focus to Balochistan,
Pakistan. Journal of the Saudi Society of Agricultural Sciences, v.18, p.188-194, 2019. Available from: $<$ https://www.sciencedirect. com/science/article/pii/S1658077X16302168>. Accessed: Apr. 8, 2020. doi: 10.1016/j.jssas.2017.05.001.

CHATTERJEE, D. et al. An empirical knowledge production function of agricultural research and extension: The case of the University of California Cooperative Extension. Technological Forecasting \& Social Change, v.134, p.290-297, 2018. Available from: $\quad<$ https://www.sciencedirect.com/science/article/pii/ S0040162517315408?via\%3Dihub>. Accessed: Apr. 8, 2020. doi: 10.1016/j.techfore.2018.06.037.

CHEN, D. Q.; HE, Y. Y. Concealed reality- the rise and politics of American for-profit universities. Higher education exploration, n.12, p.53-60, 2015. Available from: <http://www.wanfangdata. com.cn/details/detail.do?_type $=$ perio\&id $=$ tjts201512010>. Accessed: Dec. 13, 2019. doi: 10.3969/j.issn.16739760.2015.12.010.

CHEN, S. C. An innovative model of Agricultural Technology Extension-Xinong mode. Journal of northwest a\&f university (SOCIAL SCIENCE EDITION), v.13, n.1, p.1-5, 2013. Available from: <http://www.wanfangdata.com.cn/details/detail. do? type $=$ perio\&id $=x b n l k j d x x b-s h 201301001>$. Accessed: Dec. 13, 2019. doi: CNKI:SUN:NLXS.0.2013-01-003.

CHAPMAN, L. J. et al. Promoting occupational health in agriculture at the University of Wisconsin-Madison. Wisconsin medical journal, v.91, n.12, p.685-688, 1992. Available from: $<$ https://www.ncbi.nlm.nih.gov/pubmed/1471357>. $\quad$ Accessed: Dec. 14, 2019.

CPC CENTRAL COMMITTEE. Some opinions on accelerating the innovation of agricultural science and technology and continuously enhancing the supply guarantee ability of agricultural products, Beijing, 2012. Available from: $<\mathrm{http}: / /$ www.moa.gov.cn/ztzl/yhwj/zywj/201202/t20120215_2481552. $\mathrm{htm}>$. Accessed: Dec. 13, 2019.

FIAZ, S. et al. Achieving food security in the Kingdom of Saudi Arabia through innovation: Potential role of agricultural extension. Journal of the Saudi Society of Agricultural Sciences, v.17, n.4, p.365-375, 2018. Available from: $<$ https://www.sciencedirect.com/ science/article/pii/S1658077X16300996>. Accessed: Dec. 13, 2019. doi: $10.1016 /$ j.jssas.2016.09.001.

GU, J. F. et al. A review of the methodology of wuli-shili-renli. Transportation system engineering and information, v.7, n.6, p.51-60, 2007. Available from: <http://www.wanfangdata.com. $\mathrm{cn} /$ details/detail.do?_type=perio\&id=jtysxtgcyxx200706007 $>$. Accessed: Dec. 14, 2019. doi: 10.3969/j.issn.10096744.2007.06.007.

GUO, J.; LUO, L. L. The solution of WSR system methodology to the complexity of science and technology evaluation system. Research on Dialectics of nature, n.12, p.78-83, 2013. Available from: $<$ http://mall.cnki.net/magazine/Article/ZRBZ201312017.htm>. Accessed: Dec. 14, 2019. doi: CNKI:SUN:ZRBZ.0.2013-12-017.

HE, D. G. Innovation of agricultural science and technology extension service and "agriculture and Forestry University Model". China Science and Technology Forum, n.11, p.155-158, 2012. Available from: <http://www.cqvip.com/ QK/91762X/201211/43700315.html>. Accessed: Dec. 14, 2019. doi: CNKI:SUN:ZGKT.0.2012-11-027. 
JI, B. Y. et al. An evaluation of the design and construction of energy management platform for public buildings based on WSR system approach. Kybernetes, v.47, n.8, p.1549-1568, 2018. Available from: <https://www.emerald.com/insight/content/ doi/10.1108/K-07-2017-0265/full/html>. Accessed: Dec. 14, 2019. doi: $10.1108 / \mathrm{K}-07-2017-0265$.

LISTED, N. The relationship of the Council for Agricultural Science and Technology (CAST) and the College of Agriculture, Iowa State University, Ames, Iowa. Veterinary and human toxicology, v.21, n.3, p.225-226, 1979. Available from: <http:// med.wanfangdata.com.cn/Paper/Detail/PeriodicalPaper PM462748>. Accessed: Dec. 13, 2019.

LI, G. C. Shunping County: special forest and fruit industry paves the way to become rich. Hebei Economic Daily, 2019. 05.21(region). Available from: <http://www.hbjjrb.com/ system/2019/05/21/019648505.shtml>. Accessed: Dec. 14, 2019. doi: CNKI:SUN:LYHB.0.1998-01-011.

LI, Z. M.; GAO, Q. J. An empirical study on the innovation of organizational model of agricultural technology extension in University-Research on Quzhou agricultural extension of China Agricultural University. Scientific management research, v.32, n.18, p.107-110, 2012. Available from: <http://www.cnki.com. cn/Article/CJFDTotal-KJGL201218024.htm>. Accessed: Dec. 13 2019. doi: 10.3969/j.issn.1000-7695.2012.18.023.

LIN, X. Y. et al. Research on knowledge management performance evaluation based on WSR system theory and triangular fuzzy number. Modern intelligence, n.6, p.6-9, 2013. Available from: $<$ http://www.cnki.com.cn/Article/CJFDTotal-XDQB201306001. htm>. Accessed: Dec. 14, 2019. doi: 10.3969/j.issn.10080821.2013.06.002.

MINISTRY OF EDUCATION. Unscramble 《Action plan for revitalizing science and technology innovation in rural areas of colleges and Universities (2018-2022)》, Introduction of relevant work[EB/OL]. Available from: <http://www.moe. gov.cn/fbh/live/2019/50736/twwd/201906/t20190612_385569. html,2019>. Accessed: Sep. 3, 2020.

MINH, T. T. Unpacking the systemic problems and blocking mechanisms of a regional agricultural innovation system: An integrated regional-functional-structural Analysis. Agricultural Systems, v.173, p.268-280, 2019. Available from: <https:// econpapers.repec.org/article/eeeagisys/v_3a173_3ay_3a2019 3ai 3ac 3ap 3a268-280.htm>. Accessed: Apr. 8, 2020. doi: 10.1016/j.agsy.2019.03.009.

MOYO, R.; SALAWU, A. A survey of communication effectiveness by agricultural extension in the Gweru district of Zimbabwe. Journal of Rural Studies, v.60, p.32-42, 2018. Available from: <https://www.sciencedirect.com/science/article/ abs/pii/S0743016717308288>. Accessed: Apr. 8, 2020. doi: 10.1016/j.jrurstud.2018.03.002.

PAN, Y.; SINGHAL, S. Agricultural extension, intra-household allocation and malaria. Journal of Development Economics, v.139, n.c, p.157-170, 2019. Available from: <https://econpapers. repec.org/article/eeedeveco/v 3a139 3ay 3a2019 3ai 3ac 3 ap_3a157-170.htm>. Accessed: Dec. $\overline{13}, \overline{2019}$. doi: $10 . \overline{1016 / \mathrm{j}}$. jdeveco.2019.03.006.

REID, S. R. M. University extension and rural tourism enterprise development: A rare Australian case. Journal of Hospitality,
Leisure, Sport \& Tourism Education, v.23, p.10-17, 2018. Available from: <https://www.sciencedirect.com/science/article/ abs/pii/S1473837618300091?via\%3Dihub>. Accessed: Apr. 11, 2020. doi: 10.1016/j.jhlste.2018.04.003.

REZVANFAR, A. et al. An investigation of the behaviour of agricultural extension and education engineering students in Tehran University towards employability. Procedia - Social and Behavioral Sciences, v.152, p.65-69, 2014. Available from: $<$ https:// www.sciencedirect.com/science/article/pii/S1877042814052227>. Accessed: Apr. 11, 2020. doi: 10.1016/j.sbspro.2014.09.155.

RACHEL, M.; ABIODUN, S. A survey of communication effectiveness by agricultural extension in the Gweru district of Zimbabwe. Journal of Rural Studies, v.60, p.32-42, 2018. Available from: <https://www.sciencedirect.com/science/article/ abs/pii/S0743016717308288?via\%3Dihub>. Accessed: Dec. 14, 2019. doi: 10.1016/j.jrurstud.2018.03.002

SATTAKA, P. et al. Agricultural extension services to foster production sustainability for food and cultural security of glutinous rice farmers in Vietnam. Kasetsart Journal of Social Sciences, v.38, n.1, p.74-80, 2017. Available from: <https://www. sciencedirect.com/science/article/pii/S2452315116301576>. Accessed: Dec. 13, 2019. doi: 10.1016/j.kjss.2016.05.003.

STUART R. M. REID. University extension and rural tourism enterprise development: A rare Australian case. Journal of Hospitality, Leisure, Sport \& Tourism Education, v.23, p.10-17, 2018. Available from: <https://www.sciencedirect.com/science/ article/abs/pii/S1473837618300091>. Accessed: Dec. 14, 2019. doi: $10.1016 /$ j.jhlste.2018.04.003.

SHE L Z. An empirical analysis of WSR system model of large projectmanagement. Journal of Civil Engineering, v.39, n.6, p.111114, 2006. Available from: <https://www.ixueshu.com/document/ d2ef2e3ca188c3e1261a51e0c5595a27318947a18e7f9386. html>. Accessed: Dec. 14, 2019. doi: 10.3321/j.issn:1000131X.2006.06.020.

TRUE, A. C. The Association of American Agricultural Colleges and Experiment Stations. Science, v.10, n.239, p.110113, 1899. Available from: <https://science.sciencemag.org/ content/10/239/110>. Accessed: Jun. 17, 2020. doi: 10.1126/ science. 10.239.110

TANG, G. H. et al. The practice and exploration of the multi-mode extension service of Nanjing Agricultural University. Science and technology management research, n.17, p.93-96, 2015. Available from: <http://www.cqvip.com/QK/96013X/201517/665978598. html $>$. Accessed: Dec. 14, 2019. doi: 10.3969/j.issn.10007695.2015.17.017.

TIAN, S. Y.; CHEN, W. On the base construction of New Rural Development Research Institute. Higher agricultural education, n.12, p.113-116, 2013. Available from: <http://www.cqvip.com/ QK/82889X/201312/48369614.html>. Accessed: Dec. 14, 2019. doi: 10.3969/j.issn.1002-1981.2013.12.029.

TAO, J. G. Analysis framework of organizational crisis management system based on WSR Methodology. Journal of University of Electronic Science and Technology (SOCIAL SCIENCE EDITION), n.1, p.27-33, 2015. Available from: <http://www. wanfangdata.com.cn/details/detail.do?_type=perio\&id=dzkjdxxbshkx201501006>. Accessed: Dec. 14, 2019. doi: 10.14071/j.10088105(2015)01-0027-07. 
VERMA, P.; SINHA, N. Integrating perceived economic wellbeing to technology acceptance model: The case of mobile based agricultural extension service. Technological Forecasting \& Social Change, v.126, p.207-216, 2018. Available from: <https://www.sciencedirect.com/science/ article/pii/S0040162516303316>. Accessed: Dec. 13, 2019 doi: 10.1016/j.techfore.2017.08.013.

WANG, Q.; LI, S.Q. Shale gas industry sustainability assessment based on WSR methodology and fuzzy matter-element extension model: The case study of China. Journal of Cleaner Production, v.226, p.336-348, 2019. Available from: <https:// www.sciencedirect.com/science/article/pii/S0959652619310625>. Accessed: Apr. 11, 2020. doi: 10.1016/j.jclepro.2019.03.346.

WEN, F. J. et al. "Government-Industry-University-ResearchPromotion"Collaborative Innovation Mechanism Construction to Promote the Development of Agricultural Machinery Technology. IFAC Papers OnLine, v.51, n.17, p.552-559, 2018. Available from: $\quad<$ https://www.sciencedirect.com/science/article/pii/ S2405896318312655>. Accessed: Dec. 14, 2019. doi: 10.1016/j. ifacol.2018.08.147.

WANG, H. F. et al. The theoretical exploration of reconstructing the framework model of agricultural extension. Journal of northwest a\&f university (SOCIAL SCIENCE EDITION), v.17, n.4 p.90-98, 2017. Available from: <http://www.wanfangdata.com. $\mathrm{cn} /$ details/detail.do? type $=$ perio\&id $=$ xbnlkjdxxb-sh201704013>.
Accessed: Dec. 14, 2019. doi: 10.13968/j.cnki.10099107.2017.04.12

XIAO, K. Y.; ZENG, X. Q. Research on incentive mode of using institutional knowledge base for scientific researchers based on WSR. Information theory and Practice, n.5, p.81-84, 2012. Available from: <http://www.cqvip.com/ QK/95770X/201205/41879489.html>. Accessed: Dec. 14, 2019. doi: CNKI:SUN:QBLL.0.2012-05-020.

XUE, H. F. et al. Analysis of project management system based on WSR Methodology. Scientific decision making, n.3, p.1-13, 2012. Available from: <http://www.cnki.com.cn/Article/CJFDTotalKXJC201203003.htm>. Accessed: Dec. 14, 2019. doi: 10.3773/j. issn.1006-4885.2012.03.001.

ZHANG, W. F. et al. Closing yield gaps in China by empowering smallholder farmers. Nature, v.537, p.671-674, 2016. Available from: <http://www.nature.com/articles/nature19368>. Accessed: Apr. 16, 2020. doi: 10.1038/nature19368.

ZHANG, H. L. et al. "Three station chain link" The theory and practice of innovation driving the development of the whole industry chain of modern agriculture - Take apple industry as an example". Scientific management research, n.4, p.60-64, 2018. Available from: <http://www.cqvip.com/ QK/95997X/20184/676452161.html>. Accessed: Dec. 14, 2019. doi: CNKI:SUN:KXGY.0.2018-04-016. 